Copyright (C) 2021 by Cherkas Global University

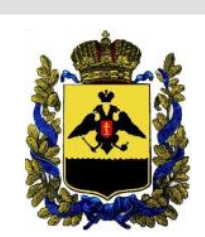

Published in the USA

Bylye Gody

Has been issued since 2006.

E-ISSN: 2310-0028

2021. 16(4): 1996-2004

DOI: $10.13187 /$ bg.2021.4.1996

Journal homepage:

https://bg.cherkasgu.press

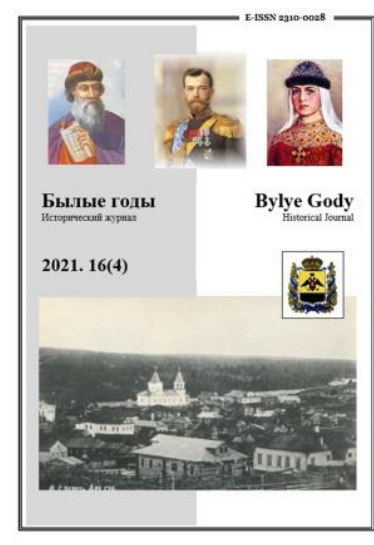

\title{
The Reflection of the Initial Period of the Russian-Japanese War in the Journal “Ogonek" (January - March 1904)
}

\author{
Dmitry S. Sknarev a , *, Zulfira S. Zyukina a, Ekaterina S. Kozlovskaya a, Nadezhda M. Suzdalova a \\ a Peoples Friendship University of Russia (RUDN University), Moscow, Russian Federation
}

\begin{abstract}
The article examines the initial period of the Russo-Japanese war (January-March 1904) based on the materials of the weekly Russian journal "Ogonek".

The authors used the files of the journal "Ogonek" as materials. At the specified time, the journal was a weekly issue which focused on the mass reader. In total, 14 issues of the journal were reviewed (from the 1st to the 14th for 1904), which covered the pre-war period and the initial military period (up to the presentation on the pages of the journal of the events of March 31,1904 - the death of the armadillo "Petropavlovsk").

In conclusion, the authors state that the emphasis in the coverage of the events of the initial period of the Russian-Japanese war in the journal was on visualization. Using the photo series, a holistic picture of the events of the war was formed. At the same time, the editor and correspondents of the newspaper tried to present a photo series taking into account the regional specifics. There was a place not only for Russians, but also for Tungus, and Chinese, and Japanese. Trying not to repeat the publication of materials for the weekly journal "Niva", the editor of "Ogonek" did not publish the official documents about the beginning of the war, but focused on presenting the process of reading the supreme manifesto by the residents of the capital. It was quite an interesting move, which demonstrated the interest of the residents of the capital to the message about the beginning of the war.

Another constant theme that was visualized on the pages of "Ogonek" was the volunteer movement to the front, in which not only the lower ranks of the army, officers, officials and generals took part, but also representatives of the ruling dynasty. This theme formed the image of the unity of the Russian people in the fight against the aggressor. That was also very important in the context of the conflict.

Keywords: Russian-Japanese war, initial period, russian journal "Ogonek", publications, January March 1904, visualization.

\section{1. Введение}

Влияние периодической печати на массового читателя, особенно в условиях военного конфликта, трудно недооценить, тем более если речь идет о конфликте периода XX века, когда средства массовой информации получили широкое распространение. В этих условиях на периодическую печать возлагались задачи по формированию общественного мнения, героизации жертвенного порыва собственной армии в зоне боевых действий. В данной статье мы хотели бы на примере российского массового журнала «Огонек» рассмотреть начальный период русско-японской войны (январь - март 1904 г.), выявить особенности в отражении на страницах журнала событий на Дальнем Востоке как накануне, так и в начальный период войны.
\end{abstract}

\footnotetext{
${ }^{*}$ Corresponding author

E-mail addresses: sknar@list.ru (D.S. Sknarev)
} 


\section{2. Материалы и методы}

В качестве материалов нами были использованы подшивки российского журнала «Огонек» за период январь - март 1904 г. В это время журнал являлся еженедельным изданием, ориентированным на массового читателя. Всего нами было рассмотрено 14 номеров журнала (с 1-го по 14-й за 1904 г.), которые охватывали предвоенный период и начальный военный (вплоть до представления на страницах журнала событий 31 марта 1904 г. - гибели броненосца «Петропавловск»).

Ввиду специфики нашего исследования в работе был применен метод контент-анализа, предусматривающий подробный анализ контента, в роли которого выступает журнал «Огонек». Также были применены методы сравнительно-исторического и синхронного изучения. Сравнительно-исторический метод позволил сравнить еженедельный журнал «Огонек» с аналогичным изданием «Нива», синхронный - рассмотреть события начального периода русскояпонской войны в контексте с другими событиями общественной жизни.

\section{3. Обсуждение}

Приступая к обзору историографии, важно сразу пояснить, что рассмотрение военных конфликтов в целом, и русско-японской войны в частности, на примере периодической печати периода войны является достаточно распространенным явлением в современной историографии.

Авторами привлекались в качестве источника информации не только центральные и региональные издания, но и сам журнал «Огонек». К примеру, Л.Г. Полякова рассматривала карикатуру как вид пропаганды в годы Первой мировой войны на материалах журнала «Огонек» (Polyakova, 2016).

Русско-японскую войну на публикациях журнала «Вестник Европы» изучал Н.Ю. Николаев (Николаев, 2012). На материалах «Самарских епархиальных ведомостей» была исследована данная тема таким автором, как А.О. Буранок (Буранок, 2007). В свою очередь В.П. Левина использовала для аналогичной работы газету «Владивостокские епархиальные ведомости» (Левина, 2014). Для изучения темы войны с Японией привлекался и такой авторитетный специализированный источник, как журнал «Война с Японией» (Denisenko et al., 2021).

Из более узких тем исследователями затрагивались действия владивостокского крейсерского отряда на примере периодических изданий 1904-1905 годов, к данной теме обращался С.В. Пышнограев (Пышнограев, 2012); к особенностям организации контроля над периодической печатью на Дальнем Востоке России в начале XX века - М.А. Бордаков (Бордаков, 2013); А.А. Подшивалов и А.И. Подшивалов рассматривали крейсер «Варяг» как пропагандистский символ эпохи (Подшивалов, Подшивалов, 2019); группа авторов А.М. Мамадалиев, Р.М. Аллалыев, Н.В. Мику и А. Медико обратились к теме сравнения боевого состава русского и японского флотов (Mamadaliev et al., 2020). Е.А. Гладкая исследовала тему русско-японской войны в сознании широких слоев населения России в начале XX века (Гладкая, 2008), а И.А. Хвостова - причины поражения России в войне с Японией на материалах «Нижегородской земской газеты» (Хвостова, 2015). Дальневосточную политику России на публикациях газеты «Санкт-Петербургские ведомости» рассматривал Е.В. Пирайнен (Пирайнен, 2013).

Помимо этого, авторы обращались и к другим темам, связанным с русско-японской войной. Так, например Р.А. Саутин и Е.М. Кунжаров на примере журнала «Кадетская перекличка» рассмотрели участие сибирских воинских формирований в военных конфликтах начала ХX века (Саутин, Кунжаров, 2016). Н.Ю. Николаев на материалах журнала «Вестник Европы» исследовал тему участия генерала Куропаткина в русско-японской войне (Николаев, 2019). В то же время И.В. Ставецкая и Н.Ю. Гаврилова на материалах газет «Тобольский губернский вестник» и «Сибирская торговая газета» рассмотрели благотворительную деятельность населения Тобольской губернии периода русско-японской войны (Stavetskaya, Gavrilova, 2020), а М.М. Кирилов обратился к изучению национальных частей, принимавших участие в годы русско-японской войны (Kirilov, 2020).

\section{4. Результаты}

Хронологические рамки данного исследования охватывают освещение событий января - марта 1904 г. на страницах журнала «Огонек», в связи с чем основная часть работы была разделена нами на предвоенные публикации (1-4-й номера журнала) и публикации военного времени (5-14-й номера журнала).

\section{Предвоенные публикации}

Первый номер еженедельного иллюстрированного журнала «Огонек» вышел в свет 9 декабря 1899 г. Журнал в то время являлся литературно-художественным приложением к газете «Биржевые ведомости». Его редактором и издателем являлся Станислав Максимилианович Проппер. В рассматриваемый нами период журнал издавался на 8 страницах, а с 1908 г. - на 20 страницах. 


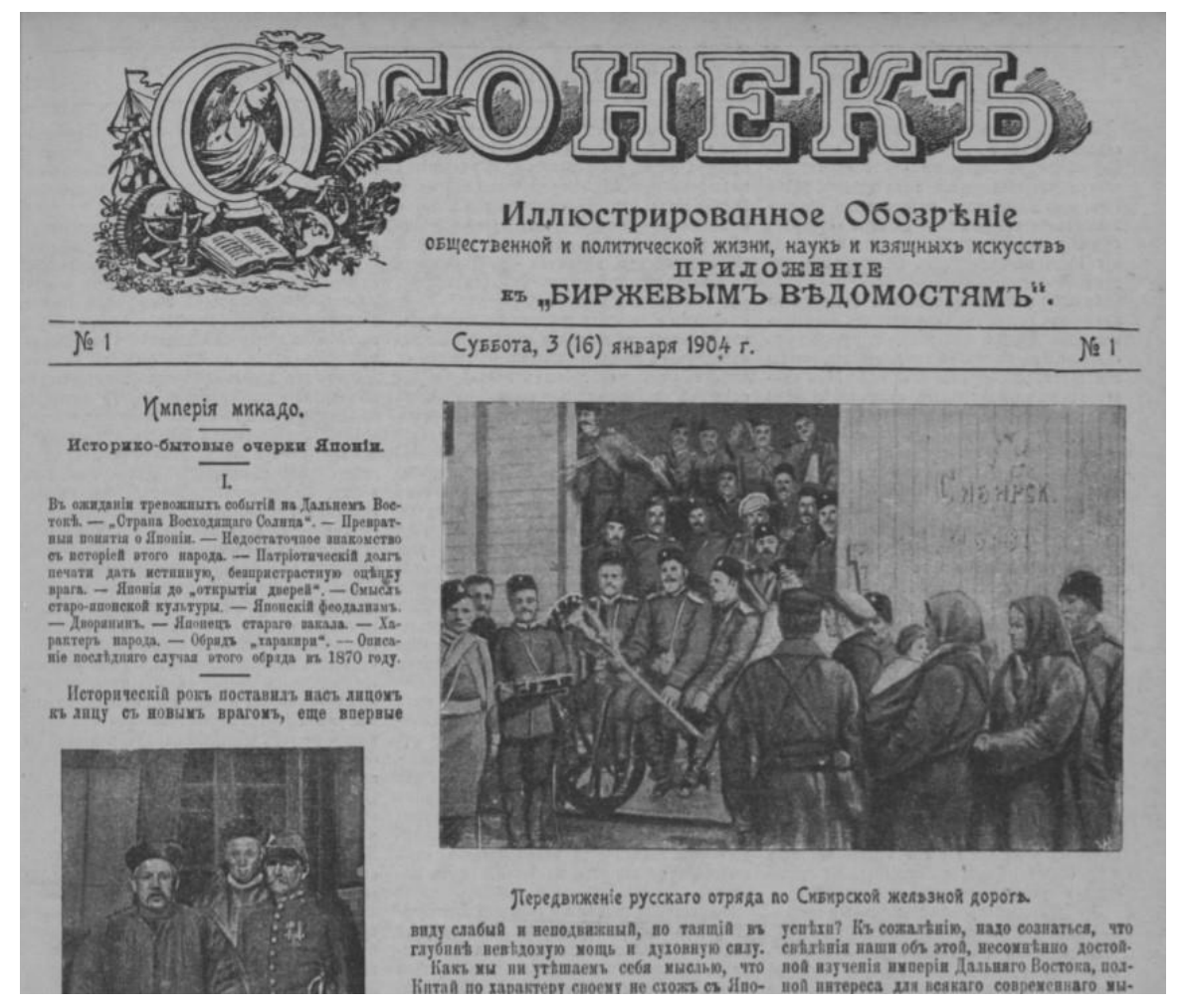

Рис. 1. «Огонек» - иллюстрированное приложение

К началу 1904 г. российское общество находилось в состоянии ожидания каких-то событий на Дальнем Востоке. Сложно было сказать, было ли это началом открытых боевых действий между Россией и Японией, или все бы и закончилось на уровне дипломатических демаршей.

Так или иначе, но японская или дальневосточная тематика вызывала повышенный интерес у читателя, и в журнале «Огонек» эти материалы постоянно публиковались.

В 1-м номере за 1904 г. от 3 января была опубликована статья К. Военского «Империя микадо» (Военский, 1904: 1-6). Эта публикация заняла больше 60 \% площади журнала и, помимо текста, содержала иллюстрированный материал на дальневосточную тематику (например, фотография о передвижении русского отряда по Сибирской железной дороге и фотография «Японская пехота на отдыхе во время маневров»). На последней странице номера была опубликована фотография «Железная дорога из Сеула в Чемульпо».

10 января был издан 2-й номер «Огонька», который отличался уже большей милитаризацией. На первой странице была опубликована фотография о том, как наместник царя на Дальнем Востоке производил смотр частей русской армии в Порт-Артуре, а также группа из шести фотографий, которая иллюстрировала рода войск русской и японской армий (последний рисунок мы решили представить в качестве примера - Рисунок 2).

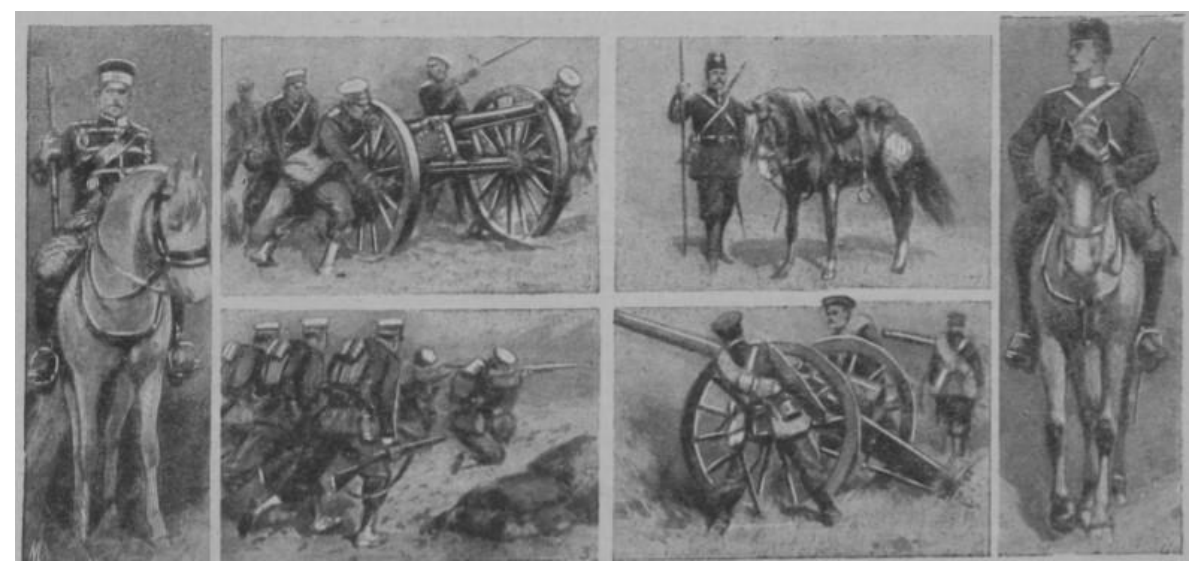

Рис. 2. Типы русских и японских военнослужащих 
Публикация Рисунка 2 в журнале «Огонек» свидетельствовала о том, что в ближайшей перспективе может произойти военное столкновение между Россией и Японией. На 12-й странице журнала были опубликованы две фотографии русской армии на Дальнем Востоке: «Русские войска на пути к Мукдену», где представлено движение русских войск с песнями, и «Праздничные развлечения русских войск в маньчжурской деревушке». Обе фотографии рисовали непринужденный и даже беспечный образ русской армии, которая, благодаря своей силе, не чувствовала угрозы неприятеля. В то же время на 13-й странице были опубликованы четыре фотографии японской тематики: две фотографии касались лидеров японских вооруженных сил (генерал Терутчи - японский военный министр и фельдмаршал Катцура - японский министр-президент), на двух других фотографиях были изображены приготовления Японии к войне: на первой - постройка японцами железной дороги между Сеулом и Фузаном, а на второй - новейшие японские крейсера «Ривадия» и «Морено».

На последней странице 2-го номера журнала была опубликована заметка «Японские нравы», в которой редактор впервые упомянул о проблемах во взаимоотношениях между Россией и Японией: «Известный английский путешественник-этнограф Дуглас Слэден прекрасно ознакомился с нравами народа, дерзающего теперь вступить на борьбу с нашим отечеством...» (Японские нравы, 1904: 16). Иными словами, запах будущей войны уже ощущался и ее начало было лишь делом времени.

В 3-м номере журнала за 17 января было опубликовано продолжение работы К. Военского «Империя микадо» (Военский, 1904а: 17-22). Что касается иллюстраций, то дальневосточной тематике были посвящены только фотографии на последней (24-й) странице номера. Здесь были представлены представители дипломатических миссий (Барон фон Розен - русский посланник в Токио, Курино - японский посланник в Санкт-Петербурге и А. Павлов - русский посланник в Корее), а также две фотографии из жизни в Японии (торговые ряды и площадь в японской деревне).

Последний предвоенный номер журнала вышел в свет 24 января 1904 г. (№ 4). На обложке журнала были опубликованы две фотографии: первая изображала общий вид Порт-Артура и его гавань, а вторая - дебаты в здании японского парламента в поддержку начала военных действий против России. Уже со следующей страницы продолжалась публикация труда К. Военского «Империя микадо» (Военский, 1904b: 17-22). Помимо этого, в журнале было опубликовано несколько фотографий, иллюстрирующих события на Дальнем Востоке, среди них были «Вход в порт-артурскую гавань», «Передвижения русских войск в Маньчжурии».

На протяжении января 1904 г. журнал «Огонек» публиковал материалы ознакомительного характера. В первую очередь это касается работы К. Военского «Империя микадо», другие материалы публиковались на уровне заметок о жизни в Японии. Важное значение для информирования читателя о происходящем в Японии отводилось иллюстрациям. Именно от них читатель получал сигналы о надвигающихся событиях (например, Рисунок 2).

\section{Публикации военного времени}

Как известно, в ночь на 27 января 1904 г. 8 японских миноносцев провели торпедную атаку на русскую эскадру, которая стояла на внешнем рейде Порт-Артура. В результате повреждения получили два лучших русских броненосца «Цесаревич» и «Ретвизан» и бронепалубный крейсер «Паллада». В тот же день японская эскадра из 6 крейсеров и 8 миноносцев атаковала около Чемульпо русский крейсер «Варяг» и канонерскую лодку «Кореец», которые в результате боя были затоплены. В тот же день император Николай II подписал Манифест о начале войны.

31 января вышел в свет 5-й номер журнала «Огонек», на обложке которого были опубликованы фотографии: «Общий вид города Владивостока» и «Общий вид Порт-Артура и его восточного и западного бассейнов». Далее было опубликовано продолжение работы К. Военского «Империя микадо» (Военский, 1904c: 34-35). Из других иллюстраций, посвященных русско-японской тематике, были опубликованы рисунки «Японская артиллерия во время действия», «Военный совет на японском судне», а также «Японский император в военной форме».

7 февраля вышел 6-й номер журнала. «Огонек» не пошел по пути еженедельного журнала «Нива», который напечатал Манифест Николая II на своих страницах. Тем не менее были опубликованы оригинальные рисунки из серии «На улицах Петербурга в дни войны»: «Чтение экстренных прибавлений» и «Чтение Высочайшего манифеста». На обложке журнала были опубликованы первые фотографии из действующей русской армии: «Сторожевые посты в окрестностях Инкоу» и «Передовой кавалерийский отряд на пути к устьям реки Ялу». В начальный период войны интерес со стороны читателя вызывало все, что касалось Японии, но в обществе было смутное представление о географическом положении агрессора. В результате в 6-м номере были опубликованы и две топографические карты - «Карта Маньчжурии и Кореи», а также «Японское море с Японией». Что касается публикаций о Японии, то в этом номере была опубликована заметка «Православие в Японии» (Православие в Японии, 1904: 43).

14 февраля 1904 г. вышел 7-й номер журнала. На его обложке была опубликована фотография командующего Маньчжурской русской армией генерал-адъютанта А.Н. Куропаткина. Первой статьей в номере стала работа Б. Павлова «Во что обходятся войны» (Павлов, 1904: 49-50). В иллюстрациях были представлены и участники боя у Порт-Артура (контр-адмирал князь Ухтомский, старший флагман Тихоокеанской эскадры, капитан 1-го ранга Косович, командир крейсера «Паллада» и капитан 2-го ранга 
Н.О. фон-Эссен, командир крейсера «Новик»). Отдельно были представлены и участники боя у Чемульпо (Рисунок 3). В этом же номере была опубликована заметка автора под псевдонимом «Стрелок» «Боевые качества японских войск» (Стрелок, 1904: 54). Внимание было уделено и теме мобилизации. В связи с этим на последней странице номера были опубликованы две фотографии: «Казаки на сборном пункте» и «На пути к мобилизационным пунктам на Дальнем Востоке».

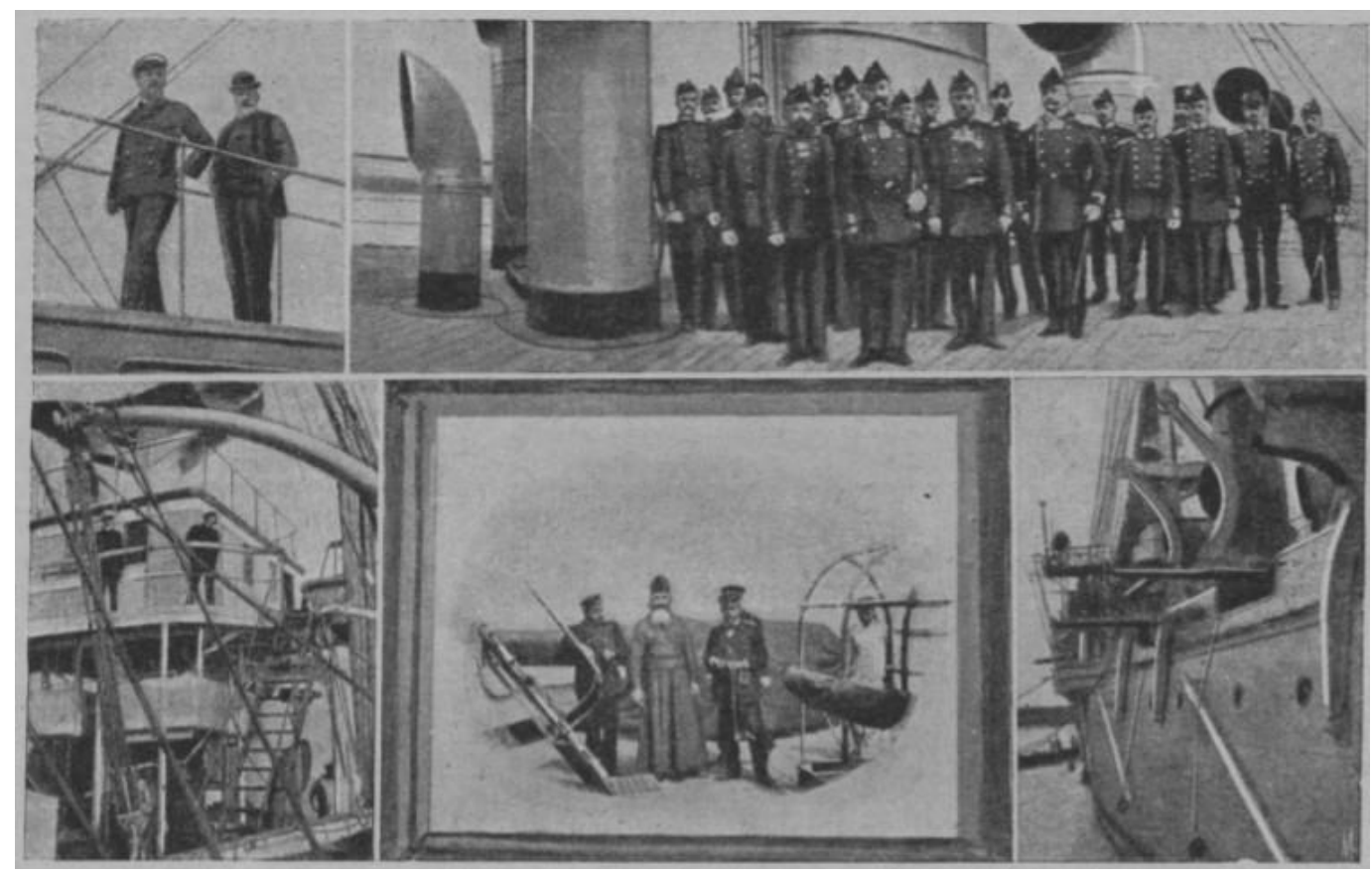

Рис. 3. К геройской гибели крейсера «Варяг» в бою у Чемульпо с 14 японскими судами:

1) капитан 1-го ранга Григорович на «Варяге»;

2) группа офицеров крейсера «Варяг»;

3) мостик «Варяга»;

4) священник «Варяга»;

5) военное снаряжение судна.

Вышедший 21 февраля 8-й номер «Огонька», наряду с иллюстрациями русских командиров разных уровней (генерал-лейтенант К.Н. Смирнов, комендант крепости Порт-Артур; капитан 1-го ранга Н. Рейценштейн, начальник Владивостокской эскадры и капитан 1-го ранга Вирен, командир крейсера «Баян», участник боя у Порт-Артура), опубликовал и рисунки из жизни русской армии: «Привал у устья реки Ялу» и «Расчистка железнодорожного пути в Маньчжурии». На страницах этого номера были опубликованы и фотографии добровольцев. Желание уйти добровольцами на фронт изъявляли как лица императорской фамилии, например великий князь Кирилл Владимирович (4-й в династийном календаре по состоянию на 1917-й год), так и нижние чины, например старший унтер-офицер Алексей Сахаров, кавалер 4 георгиевских крестов, служащий в охране царя.

28 февраля в 9-м номере журнала на обложке была опубликована фотография «Наши военачальники на Дальнем Востоке», на которой были изображены командующий Маньчжурской армией генерал-адъютант А.Н. Куропаткин и командующий Тихоокеанской эскадрой вице-адмирал C.О. Макаров. В этом номере также следовало продолжение работы К. Военского «Империя микадо» (Военский, 1904d: 65-70).

6 марта вышел в свет 10-й номер журнала «Огонек», но обложке которого была изображена высадка японских войск в Чемульпо (10 февраля 1904 г.), а также атака крейсером «Новик» японской эскадры после неудачного нападения на Порт-Артур в ночь на 27 января. В этом же номере была опубликована фотография экипажа канонерской лодки «Кореец, а также впервые использован новый жанр публикации фотоматериалов «Допрос японских шпионов, скрывавшихся под видом кули и пойманных железнодорожным разъездом в Маньчжурии».

13 марта выходит следующий номер журнала. Центральное место в нем уделяется проводам генерала Куропаткина на фронт. В связи с этим на обложке публикуется фотография «Поднесение генерал-адъютанту Куропаткину икон и стяга в зале Благородного собрания в Москве, в присутствии столичных властей и представителей сословия». Очевидно, что война требовала напряжения сил всего российского общества, одними из первых откликнулись женщины - представители дамских кружков и комитетов. В качестве иллюстрации этого примера в журнале был опубликован рисунок 
«Приготовление белья и бинтов для нужд войск дамским аристократическим кружком в СанктПетербурге». Корреспонденты «Огонька» хотели показать войну во всех ее красках. Так, на 82-1 странице был опубликован отъезд (эвакуация) русских крестьян из города Дальнего, который становился театром военных действий. Уделялось внимание и теме подготовительных мероприятий, например выгрузке провианта и военных запасов в Порт-Артуре, а также переправе русских войск через реку Ялу в условиях ледохода.

20 марта был опубликован 12-й номер журнала, который претендовал на освещение роли средних командиров в войне и пехотных подразделений русской армии. Так, на обложке были опубликованы фотографии лейтенантов Зарубаева и Берлинга, а также инженер-механика Блинова. Действия русской пехоты иллюстрировала фотография преследования русскими лыжниками хунхузов в Маньчжурии. Целым циклом фотографий была представлена тема мобилизации в Японии: «Проверка прибывших запасных перед казармами», «Японская пехота в поезде на пути к Сеулу» и «Проводы запасных в Японии». Из иллюстраций о жизни русской армии были представлены фотографии «Передвижение легкораненых на лыжах к ближайшему походному госпиталю» и «Закупка у тунгузов в Сибири оленей для военных транспортов». Также в этом номере была опубликована заметка «Современное положение Японии» (Современное положение Японии, 1904: 95-96).

Вышедший 3 апреля 13-й номер журнала был посвящен теме возвращения в Одессу экипажей крейсера «Варяг» и канонерской лодки «Кореец». На обложке в связи с этим была опубликована фотография «Торжественная встреча парохода «Малайя» с экипажами «Варяга» и «Корейца» в Одессе 19-го марта». Эта фотография была подписана - «Первый привет родины героям боя у Чемульпо». Потом были опубликованы как групповые, так и индивидуальные фотографии участников знаменитого боя: «Командующий войсками Одесского военного округа барон Каульбарс приветствует старшего офицера экипажа «Варяга», капитана 2-го ранга В.В. Степанова», «Священник крейсера «Варяг» отец Михаил Руднев, награжденный наперстным крестом на Георгиевской ленте», «Барон Каульбарс поздравляет экипажи «Варяга» и «Корейца» с геройским подвигом у Чемульпо», «Перенесение раненых с «Варяга» на итальянское судно «Эльба»», «Старший врач крейсера «Варяг» М.Н. Храбростин» и «Мичман П.Н. Тубонин, раненый на «Варяге» у Чемульпо и награжденный орденом Святого Георгия 4-й степени». Из японской тематики в журнале была лишь одна заметка «Свадьба в Японии» (Свадьба в Японии, 1904: 103).

10 апреля в 14-м номере журнала «Огонек» с некоторым опозданием приводился материал о гибели 31 марта на рейде Порт-Артура броненосца «Петропавловск», на котором погибли и вицеадмирал С.О. Макаров, и известный художник-баталист В.В. Верещагин. На обложке номера была помещена фотография «Доставка в Дальний продовольственных запасов и товаров на китайских джонках (плоскодонные лодки)». В качестве иллюстрации событий на войне были опубликованы фотографии «Флотилии русских миноносцев на порт-артурском рейде» и «Доставка японцами рельсов в Чемульпо для железнодорожной линии от Сеула к устью реки Ялу». Также были опубликованы две фотографии медицинских отрядов, которые отправлялись на войну. Речь шла о 3м резервном медицинском отряде и о 5-м резервном санитарном отряде. В этом же номере была опубликована фотография екатеринославского губернатора генерал-лейтенанта графа Ф.Э. Келлера, который также отправился на войну.

В начальный период русско-японской войны ввиду отсутствия собственных корреспондентов на театре военных действий журнал продолжил публикацию фотоматериалов и в целом, на наш взгляд, отразил ими все главные события начавшегося противостояния.

\section{5. Заключение}

Завершая, мы хотели бы отметить, что ставка в освещении событий начального периода русскояпонской войны в журнале делалась на визуализацию. При помощи фоторяда формировалась целостная картина событий о войне. При этом редактор и корреспонденты газеты старались представить фоторяд с учетом региональной специфики. Здесь нашлось место не только русским, но и тунгусам, и китайцам, и японцам. Стараясь не повторять публикацию материалов за еженедельным журналом «Нива», редактор «Огонька» не стал публиковать официальные документы о начале войны, а сфокусировался на представлении процесса чтения высочайшего манифеста жителями столицы. Это был достаточно интересный ход, который демонстрировал интерес жителей столицы к сообщению о начале войны.

Другой постоянной темой, которая визуализировалась на страницах «Огонька» было добровольческое движение на фронт, в котором принимали участие не только нижние чины армии, офицеры, чиновники и генералы, но и представителя правящей династии. Эта тема формировала образ единства русского народа в борьбе с агрессором, что было также очень важно в условиях конфликта.

\section{6. Благодарности}

Публикация выполнена при поддержке Программы стратегического академического лидерства Рудн. / This paper has been supported by the RUDN University Strategic Academic Leadership Program. 


\section{Литература}

Бордаков, 2013 - Бордаков М.A. Особенности организации контроля над периодической печатью на Дальнем Востоке России в начале XX века // Власть и управление на Востоке России. 2013. № 2 (63). С. 76-84.

Буранок, 2007 - Буранок А.О. Русско-японская война на страницах «Самарских епархиальных ведомостей» // Знание. Понимание. Умение. 2007. № 4. С. 79-86.

Военский, 1904 - Военский К. Империя микадо // Огонек. 1904. № 1. С. 1-6.

Военский, 1904а - Военский К. Империя микадо (продолжение) // Оәонек. 1904. № 3. С. 17-22.

Военский, 1904b - Военский К. Империя микадо (продолжение) // Огонек. 1904. № 4. С. 26-30.

Военский, 1904c - Военский К. Империя микадо (продолжение) // Огонек. 1904. № 5. C. 34-35.

Военский, 1904d - Военский К. Империя микадо (продолжение) // Огонек. 1904. № 9. С. 65-70.

Гладкая, 2008 - Гладкая E.A. Русско-японская война в сознании широких слоев населения России в начале XX в. // Известия высших учебных заведений. Северо-Кавказский регион. Общественные науки. 2008. № 3 (145). С. 68-72.

Левина, 2014 - Левина В.П. «Владивостокские епархиальные ведомости» о русско-японской войне 1904-1905 гг. // Научно-методический электронный журнал Концепт. 2014. № 20. С. 491-495.

Николаев, 2012 - Николаев Н.Ю. Русско-японская война на страницах «Вестника Европы» в 1903-1905 гг. // Вестник Волгоградского государственного университета. Серия 4 «История. Регионоведение. Международные отношения». 2012. № 2 (22). С. 184-188.

Николаев, 2019 - Николаев Н.Ю. Участие А.Н. Куропаткина в русско-японской войне по страницам журнала «Вестник Европы» // Мир политики и социологии. 2019. № 6. С. 52-65.

Павлов, 1904 - Павлов Б. Во что обходятся войны // Огонек. 1904. № 7. С. 49-50.

Пирайнен, 2013 - Пирайнен Е.В. Из истории дальневосточной политики России 1895-1905 гг. (по материалам газеты «Санкт-Петербургские ведомости») // Известия СПбГЭТУ ЛЭТИ. 2013. № 10. C. 97-100.

Подшивалов, Подшивалов, 2019 - Подшивалов А.А., Подшивалов И.А. Крейсер «Варяг»: пропагандистский символ эпохи // Военно-исторический журнал. 2019. № 10. С. 91-95.

Православие в Японии, 1904 - Православие в Японии // Огонек. 1904. № 6. С. 43.

Пышнограев, 2012 - Пышнограев С.В. Действия владивостокского крейсерского отряда в периодических изданиях 1904-1905 годов // Преподавание истории в школе. 2012. № 6. С. 70-79.

Саутин, Кунжаров, 2016 - Саутин Р.A., Кунжаров Е.М. Журнал «Кадетская перекличка» как источник по истории участия сибирских воинских формирований в военных конфликтах начала ХХ в. // Проблемы социально-экономического развития Сибири. 2016. № 2 (24). С. 118-122.

Свадьба в Японии, 1904 - Свадьба в Японии // Огонек. 1904. № 13. С. 103.

Современное положение Японии, 1904 - Современное положение Японии // Огонек. 1904. № 12. C. $95-96$.

Стрелок, 1904 - Стрелок. Боевые качества японских войск // Огонек. 1904. № 7. С. 54.

Хвостова, 2015 - Хвостова И.А. Причины поражения России в войне с Японией 1904-1905 гг. по материалам «Нижегородской земской газеты» // Достижения вузовской науки. 2015. № 18. С. 13-17.

Японские нравы, 1904 - Японские нравы // Огонек. 1904. № 2. С. 16.

Denisenko et al., 2021 - Denisenko V.N., Bereznyatskaya M.A., Denisenko A.V., Yurova Yu.V. The Journal "Voina s Yaponiei” as a Historical Source // Bylye Gody. 2021. 16(3): 1491-1500.

Kirilov, 2020 - Kirilov M.M. Native Units in the Imperial Russian Army during the Russo-Japanese War of 1904-1905 // Propaganda in the World and Local Conflicts. 2020. 7(1): 3-14.

Mamadaliev et al., 2020 - Mamadaliev A.M., Allalyev R.M., Miku N.V., Médico A. The Japanese Armored Cruisers and Mine-Torpedo Forces of the Opposing Sides During the Russian-Japanese War // Bylye Gody. 2020. 55(1): 295-333.

Polyakova, 2016 - Polyakova L.G. Caricature as a type of propaganda during World War I (as illustrated by materials published in the Ogoniok magazine) // Propaganda in the World and Local Conflicts. 2016. 5(1): 12-29.

Stavetskaya, Gavrilova, 2020 - Stavetskaya I.V., Gavrilova N.Yu. Charity Gatherings of the Population of the Tobolsk Province during the Russo-Japanese War: based on the Materials of the Publications "Tobolsk Provincial Gazette" and "Siberian Trade Newspaper" (1904-1905) // Bylye Gody. 2020. 55(1): 334-344.

\section{References}

Bordakov, 2013 - Bordakov, M.A. (2013). Osobennosti organizatsii kontrolya nad periodicheskoi pechat'yu na Dal'nem Vostoke Rossii $v$ nachale XX veka [Features of the organization of control over periodicals in the Far East of Russia at the beginning of the XX century]. Vlast' $i$ upravlenie na Vostoke Rossii. 2(63): 76-84. [in Russian]

Buranok, 2007 - Buranok, A.O. (2007). Russko-yaponskaya voina na stranitsakh «Samarskikh eparkhial'nykh vedomostei» [The Russo-Japanese war on the pages of the "Samarskikh eparkhial'nykh vedomostei”]. Znanie. Ponimanie. Umenie. 4: 79-86. [in Russian] 
Denisenko et al., 2021 - Denisenko, V.N., Bereznyatskaya, M.A., Denisenko, A.V., Yurova, Yu.V. (2021). The Journal "Voina s Yaponiei” as a Historical Source. Bylye Gody. 16(3): 1491-1500.

Gladkaya, 2008 - Gladkaya, E.A. (2008). Russko-yaponskaya voina v soznanii shirokikh sloev naseleniya Rossii v nachale XX v. [The Russo-Japanese war in the consciousness of the russian general population at the beginning of the 20th century]. Izvestiya vysshikh uchebnykh zavedenii. SeveroKavkazskii region. Obshchestvennyi nauki. 3(145): 68-72. [in Russian]

Khvostova, 2015 - Khvostova, I.A. (2015). Prichiny porazheniya Rossii v voine s Yaponiei 1904-1905 gg. po materialam «Nizhegorodskoi zemskoi gazety» [The reasons for the defeat of Russia in the war with Japan in 1904-1905 based on the materials of the "Nizhegorodskoi zemskoi gazety"]. Dostizheniya vuzovskoi nauki. 18: 13-17. [in Russian]

Kirilov, 2020 - Kirilov, M.M. (2020). Native Units in the Imperial Russian Army during the RussoJapanese War of 1904-1905. Propaganda in the World and Local Conflicts. 7(1): 3-14.

Levina, 2014 - Levina, V.P. (2014). «Vladivostokskie eparkhial'nye vedomosti» o russko-yaponskoi voine 1904-1905 gg. ["Vladivostokskie eparkhial'nye vedomosti" about the Russian-Japanese war of 1904-1905.]. Nauchno-metodicheskii elektronnyi zhurnal Kontsept. 20: 491-495. [in Russian]

Mamadaliev et al., 2020 - Mamadaliev, A.M., Allalyev, R.M., Miku, N.V., Médico, A. (2020). The Japanese Armored Cruisers and Mine-Torpedo Forces of the Opposing Sides During the RussianJapanese War. Bylye Gody. 55(1): 295-333.

Nikolaev, 2012 - Nikolaev, N.Yu. (2012). Russko-yaponskaya voina na stranitsakh «Vestnika Evropy» v 1903-1905 gg. [The Russo-Japanese War on the pages of the "Bulletin of Europe" in 1903-1905]. Vestnik Volgogradskogo gosudarstvennogo universiteta. Seriya 4: Istoriya. Regionovedenie. Mezhdunarodnye otnosheniya. 2(22): 184-188. [in Russian]

Nikolaev, 2019 - Nikolaev, N.Yu. (2019). Uchastie A.N. Kuropatkina v russko-yaponskoi voine po stranitsam zhurnala «Vestnik Evropy» [A.N. Kuropatkina in the Russian-Japanese war through the pages of the journal "Vestnik Evropy"]. Mir politiki i sotsiologii. 6: 52-65. [in Russian]

Pavlov, 1904 - Pavlov, B. (1904). Vo chto obkhodyatsya voiny [What are the costs of wars]. Ogonek. 7: 49-50. [in Russian]

Pirainen, 2013 - Pirainen, E.V. (2013). Iz istorii dal'nevostochnoi politiki Rossii 1895-1905 gg. (po materialam gazety «Sankt-Peterburgskie vedomosti») [From the history of Russia's Far Eastern policy in 1895-1905. (based on materials from the newspaper "St. Petersburg Vedomosti")]. Izvestiya SPbGETU LETI. 10: 97-100. [in Russian]

Podshivalov, Podshivalov, 2019 - Podshivalov, A.A., Podshivalov, I.A. (2019). Kreiser «Varyag»: propagandistskii simvol epokhi [The cruiser "Varyag": a propaganda symbol of the era]. Voenno-istoricheskii zhurnal. 10: 91-95. [in Russian]

Polyakova, 2016 - Polyakova, L.G. (2016). Caricature as a type of propaganda during World War I (as illustrated by materials published in the Ogoniok magazine). Propaganda in the World and Local Conflicts. 5(1): 12-29.

[in Russian]

Pravoslavie v Yaponii, 1904 - Pravoslavie v Yaponii [Orthodoxy in Japan]. Ogonek. 1904. 6: 43.

Pyshnograev, 2012 - Pyshnograev, S.V. (2012). Deistviya vladivostokskogo kreiserskogo otryada v periodicheskikh izdaniyakh 1904-1905 godov [The actions of the Vladivostok cruising detachment in periodicals of 1904-1905]. Prepodavanie istorii $v$ shkole. 6: 70-79. [in Russian]

Sautin, Kunzharov, 2016 - Sautin, R.A., Kunzharov, E.M. (2016). Zhurnal «Kadetskaya pereklichka» kak istochnik po istorii uchastiya sibirskikh voinskikh formirovanii v voennykh konfliktakh nachala XX v. [The journal "Kadetskaya pereklichka" as a source on the history of the participation of Siberian military formations in military conflicts at the beginning of the XX century]. Problemy sotsial'no-ekonomicheskogo razvitiya Sibiri. 2(24): 118-122. [in Russian]

Sovremennoe polozhenie Yaponii, 1904 - Sovremennoe polozhenie Yaponii [The current state of Japan]. Ogonek. 1904. 12: 95-96. [in Russian]

Stavetskaya, Gavrilova, 2020 - Stavetskaya, I.V., Gavrilova, N.Yu. (2020). Charity Gatherings of the Population of the Tobolsk Province during the Russo-Japanese War: based on the Materials of the Publications "Tobolsk Provincial Gazette" and "Siberian Trade Newspaper" (1904-1905). Bylye Gody. 55(1): 334-344.

Strelok, 1904 - Strelok (1904). Boevye kachestva yaponskikh voisk [The fighting qualities of the Japanese troops]. Ogonek. 7: 54. [in Russian]

Svad'ba v Yaponii, 1904 - Svad'ba v Yaponii [Wedding in Japan]. Ogonek. 1904. 13: 103. [in Russian] Voenskii, 1904 - Voenskii, K. (1904). Imperiya mikado [Mikado Empire]. Ogonek. 1: 1-6. [in Russian] Voenskii, 1904a - Voenskii, K. (1904). Imperiya mikado (prodolzhenie) [Mikado Empire (continued)]. Ogonek. 3: 17-22. [in Russian]

Voenskii, 1904b - Voenskii, K. (1904). Imperiya mikado (prodolzhenie) [Mikado Empire (continued)].

Ogonek. 4: 26-30. [in Russian]

Voenskii, 1904c - Voenskii, K. (1904). Imperiya mikado (prodolzhenie) [Mikado Empire (continued)].

Ogonek. 5: 34-35. [in Russian] 
Voenskii, 1904d - Voenskii, K. (1904). Imperiya mikado (prodolzhenie) [Mikado Empire (continued)]. Ogonek. 9: 65-70. [in Russian]

Yaponskie nravy, 1904 - Yaponskie nravy [Japanese customs]. Ogonek. 1904. 2: 16. [in Russian]

\section{Отражение начального периода русско-японской войны в журнале «Огонек» (январь - март 1904 г.)}

Дмитрий Сергеевич Скнарев а, *, Зульфира Салиховна Зюкина а,

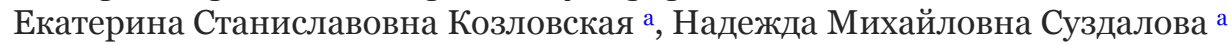

а Российский университет дружбы народов, Москва, Российская Федерация

Аннотация. В статье на материалах еженедельного российского журнала «Огонек» рассматривается начальный период русско-японской войны (январь-март 1904 г.).

В качестве материалов авторами были использованы подшивки российского журнала «Огонек», который в указанное время являлся еженедельным изданием, ориентированным на массового читателя. Всего было рассмотрено 14 номеров журнала (с 1-го по 14-й за 1904 г.), которые охватывали предвоенный период и начальный военный (вплоть до представления на страницах журнала событий 31 марта 1904 г. - гибели броненосца «Петропавловск»).

Завершая, авторы отмечают, что ставка в освещении событий начального периода русскояпонской войны в журнале делалась на визуализацию. При помощи фоторяда формировалась целостная картина событий о войне. При этом редактор и корреспонденты газеты старались представить фоторяд с учетом региональной специфики. Здесь нашлось место не только русским, но и тунгусам, и китайцам, и японцам. Стараясь не повторять публикацию материалов за еженедельным журналом «Нива», редактор «Огонька» не стал публиковать официальные документы о начале войны, а сфокусировался на представлении процесса чтения Высочайшего манифеста жителями столицы. Это был достаточно интересный ход, который демонстрировал интерес жителей столицы к сообщению о начале войны.

Другой постоянной темой, которая визуализировалась на страницах «Огонька», было добровольческое движение на фронт, в котором принимали участие не только нижние чины армии, офицеры, чиновники и генералы, но и представителя правящей династии. Эта тема формировала образ единства русского народа в борьбе с агрессором, что было также очень важно в условиях конфликта.

Ключевые слова: русско-японская война, начальный период, российский журнал «Огонек», публикации, январь-март 1904 г., визуализация.

* Корреспондирующий автор

Адреса электронной почты: sknar@list.ru (Д.С. Скнарев) 